\title{
Effect of acetazolamide and amiloride against sodium metabisulphite-induced bronchoconstriction in mild asthma
}

\author{
B J O’Connor, C T Yeo, Y M Chen-Worsdell, P J Barnes, K F Chung
}

\begin{abstract}
Background - Inhaled frusemide but not bumetanide, another loop diuretic, reduces bronchial responsiveness to sodium metabisulphite (MBS). To investigate whether the effect of frusemide could be mediated through mechanisms other than $\mathrm{Na}^{+} / \mathrm{K}^{+} / \mathrm{Cl}^{-}$cotransporter inhibition, the effects of amiloride - an inhibitor of sodium channels in the airway epithelium - and of acetazolamide - a specific inhibitor of carbonic anhydrase - against MBS challenge were studied.

Methods - In two separate randomised double blind placebo controlled studies, 10 subjects with mild asthma attended on four separate occasions to inhale $7.5 \mathrm{mg}$ amiloride or matched placebo, and $500 \mathrm{mg}$ acetazolamide or placebo, immediately before MBS challenge. The concentration of MBS required to cause a $20 \%$ fall in baseline $\mathrm{FEV}_{1}\left(\mathrm{PC}_{20}\right)$ was measured.

Results - Amiloride and acetazolamide had no effect on baseline $\mathrm{FEV}_{1}$. Amiloride had no effect against MBS challenge, but acetazolamide increased $-\log \mathbf{P C}_{20}$ from a mean (SE) of $0.75(0.09)$ to $0.98(0.06)$ representing a $0.77(0.24)$ doubling dose increase.

Conclusions - These results suggest that carbonic anhydrase activity in the airways, but not sodium flux, modulates bronchial responsiveness to $\mathrm{MBS}$ challenge. The action of frusemide is not likely to involve inhibition of carbonic anhydrase activity.
\end{abstract}

(Thorax 1994;49:1096-1098)

Administration of diuretics such as frusemide and chlorothiazide has previously been shown to improve lung function in patients with bronchopulmonary dysplasia. ${ }^{12}$ More recent studies have shown that frusemide can attenuate bronchoconstrictor responses induced by a wide range of indirect challenges including exercise, allergen, sodium metabisulphite (MBS), and adenosine in patients with asthma. ${ }^{3}$ Thus, diuretics may have direct effects on the airways in addition to improving cardiopulmonary function through their diuretic effects. The mechanism of action underlying the protective effects of the loop diuretic, frusemide, in the airways is unclear. Loop diuretics such as frusemide and bumetanide are potent inhibitors of the $\mathrm{Na}^{+} / \mathrm{K}^{+} / 2 \mathrm{Cl}^{-}$cotransporter system in the ascending loop of Henle in the renal tubule. ${ }^{4}$
Because frusemide - but not the more potent loop diuretic bumetanide - inhibits indirect challenges such as MBS and adenosine, ${ }^{5}$ it seems unlikely that inhibition of the $\mathrm{Na}^{+} / \mathrm{K}^{+} /$ $2 \mathrm{Cl}^{-}$cotransporter is the underlying mechanism of action of frusemide. Because frusemide has inhibitory effects on carbonic anhydrase activity, ${ }^{6}$ we hypothesised that carbonic anhydrase inhibition with acetazolamide may inhibit the bronchoconstrictor effect of MBS. We also investigated whether modification of sodium fluxes across the apical surface of the airway epithelium could be involved. Amiloride is another diuretic which inhibits the diffusion of sodium ions through sodium channels at the apical surface of airway epithelial cells. ${ }^{7}$ We therefore studied whether inhaled acetazolamide and amiloride could attenuate the bronchoconstrictor effects of inhaled MBS in asthmatic subjects.

\section{Methods}

SUBJECTS

Ten non-smoking subjects with mild asthma (five men) of mean (SE) age $31.3(3 \cdot 7)$ years, 93.1 (4.2)\% predicted $\mathrm{FEV}_{1}$ (table 1) gave informed consent to participate in this study which was approved by the Royal Brompton Hospital ethics committee. All patients were taking short-acting inhaled $\beta_{2}$ adrenergic agonists intermittently for the relief of wheeze, but none were on inhaled steroid therapy. None were smokers. All patients were stable for at least six months before entry to study.

PROTOCOL

Two separate randomised double blind placebo controlled studies were performed. Each subject participated in both studies. In the first study subjects inhaled either amiloride $(7.5 \mathrm{mg})$ or matched placebo, followed five minutes later by airway challenge with MBS. The study visits were separated by at least seven days. In the second study subjects inhaled either the carbonic anhydrase inhibitor acetazolamide $(500 \mathrm{mg})$ or matched placebo, followed five minutes later by MBS challenge. The study visits were also separated by at least seven days. MBS challenges were performed at the same time of the day.

Delivery of acetazolamide and amiloride Acetazolamide solution (Diamox parenteral, Lederle Laboratories, Gosport, Hants, UK; 
Table 1 Patient characteristics

\begin{tabular}{llllc}
\hline Patient & Age & Sex & Atopy & $\begin{array}{l}\text { FEV } \\
(\% \text { predicted })\end{array}$ \\
\hline 1 & 38 & F & + & $81 \cdot 1$ \\
2 & 51 & M & + & $83 \cdot 1$ \\
3 & 26 & M & + & $82 \cdot 5$ \\
4 & 21 & M & + & $102 \cdot 4$ \\
5 & 30 & F & + & $93 \cdot 1$ \\
6 & 23 & M & + & $109 \cdot 3$ \\
7 & 22 & F & + & $82 \cdot 4$ \\
8 & 33 & M & + & $95 \cdot 5$ \\
9 & 48 & + & $87 \cdot 5$ \\
10 & 21 & & $+114 \cdot 1$ \\
\hline
\end{tabular}
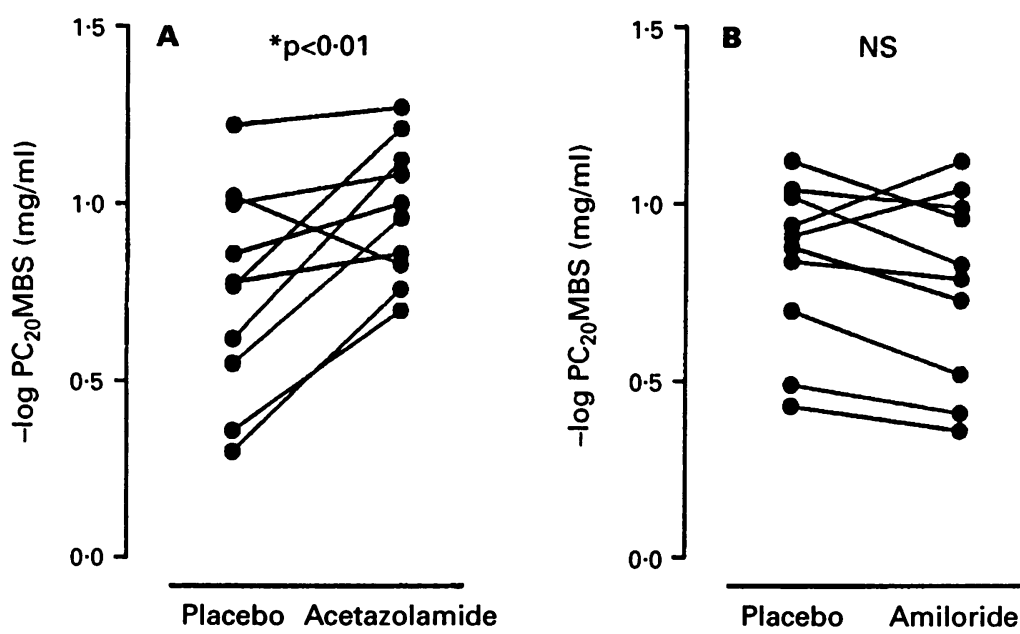

Individual $-\log P C_{20}$ values to sodium metabisulphite (MBS) challenge in 10 asthmatic subjects. (A) $-\log P C_{20}$ values after placebo and after acetazolamide; (B) $-\log P C_{20}$ values after placebo and after amiloride. Acetazolamide but not amiloride caused a significant protective effect $(p<0 \cdot 01)$.

$100 \mathrm{mg} / \mathrm{ml}$ ) nebulised at a concentration of $50 \mathrm{mg} / \mathrm{ml}$, diluted in $0.15 \mathrm{M} \mathrm{NaCl}$ to a total volume of $10 \mathrm{ml}$ (total dose $500 \mathrm{mg}$ ) was delivered. Amiloride hydrochloride was dissolved in $5 \mathrm{ml}$ water and $5 \mathrm{ml} 0 \cdot 15 \mathrm{M} \mathrm{NaCl}$ to achieve a concentration of $1 \mathrm{mg} / \mathrm{ml}$. The solution was flavoured with xylitol in order to disguise its taste. A total of $10 \mathrm{ml}$ was also nebulised. Appropriate matched diluent placebos were used, with $0.15 \mathrm{M} \mathrm{NaCl}$ for acetazolamide placebo and with $0.075 \mathrm{M} \mathrm{NaCl}$ and xylitol for amiloride placebo.

All solutions were dispensed from an ultrasonic nebuliser (de Vilbiss 99 Ultraneb, de Vilbiss, Hendon, UK), which produced particles with a mass median diameter of $4 \mu \mathrm{m}$ with a maximal output of $4 \mathrm{ml} / \mathrm{min}$. Each subject inhaled the solutions for 10 minutes.

\section{Sodium metabisulphite challenge}

MBS solutions (Sigma Chemical Company, Poole, UK) were freshly made up in $0.9 \%$ saline in doubling concentrations $(0.6 \mathrm{mg} / \mathrm{ml}$ to $160 \mathrm{mg} / \mathrm{ml}$ ) 10 minutes before each challenge. Aerosols were delivered from a nebuliser attached to a dosimeter (Morgan Nebichech Nebuliser Controller; PK Morgan Ltd, Kent, UK). The nebuliser had an output of $10 \mu \mathrm{l} /$ puff with a particle size of mass median diameter $3.5 \mu \mathrm{m}$. The dosimeter was set to nebulise for one second with a pause time of 10 seconds, and the subjects held their breath for five to eight seconds after the nebuliser was triggered. Five inhalations at each doubling concentration were taken in succession and three minutes
Table 2 Mean (SE) FEV (litres) before and five minutes after inhalation of amiloride or acetazolamide $(n=10)$

\begin{tabular}{lll}
\hline & Before & After \\
\hline Placebo & $3.31(0.36)$ & $3.13(0.33)$ \\
Acetazolamide & $3.28(0.33)$ & $3.04(0.31)$ \\
Placebo & $3.28(0.35)$ & $3.20(0.34)$ \\
Amiloride & $3.33(0.34)$ & $3.14(0.33)$ \\
\hline
\end{tabular}

after each set of inhalations at each doubling concentration $\mathrm{FEV}_{1}$ was measured using a dry wedge spirometer (Vitalograph, Buckingham, UK). The challenge started with inhalations of $0.9 \%$ saline (diluent) with subsequent measurement of $\mathrm{FEV}_{1}$ which served as control $\mathrm{FEV}_{1}$. The challenge was discontinued when the $\mathrm{FEV}_{1}$ had decreased by at least $20 \%$ of the post saline value, or when the subject had inhaled the top dose of MBS $(160 \mathrm{mg} / \mathrm{ml})$. The concentration of MBS needed to cause a $20 \%$ fall in $\mathrm{FEV}_{1}$ $\left(\mathrm{PC}_{20} \mathrm{MBS}\right)$ was then calculated by linear interpolation of the log dose-response curve.

DATA ANALYSIS

Data are reported as mean (SE). $\mathrm{PC}_{20}$ data were analysed and reported as $-\log \mathrm{PC}_{20}$. The paired $t$ test was used to determine whether amiloride or acetazolamide had a significant effect. A p value $<0.05$ was considered significant.

\section{Results}

In both studies inhalation of the diluents alone or of acetazolamide and amiloride caused no significant changes in $\mathrm{FEV}_{1}$ (table 2). Mean $-\log \mathrm{PC}_{20}$ after amiloride $(0.78(0.08))$ was not significantly altered compared with that after placebo $(0.83(0.07))$. However, mean $-\log \mathrm{PC}_{20}$ increased significantly from 0.75 $(0.09))$ after placebo to $0.98(0.06))$ after acetazolamide (figure; $\mathrm{p}<0.02$ ), representing a $0 \cdot 77(0 \cdot 24)$ doubling dilution increase.

\section{Discussion}

The aim of the study was to determine whether the mechanism of action of frusemide, which has been shown to inhibit bronchoconstrictor responses to indirect challenges, may be related to an effect on sodium transport (through a sodium channel inhibitor) or on carbonic anhydrase activity. Our results suggest that this is unlikely to be occurring through significant alterations in $\mathrm{Na}^{+}$entry channels at the apical surface of airway epithelial cells because amiloride was not effective in inhibiting MBSinduced bronchoconstriction. By contrast, acetazolamide caused a significant inhibition suggesting that carbonic anhydrase activity may modulate MBS-induced bronchoconstriction.

The dose of amiloride administered was in the same range as that given by App and colleagues who found a significant improvement in mucociliary clearance which occurred within the first 10 minutes and was maintained for a further 30 minutes after inhalation in patients with cystic fibrosis. ${ }^{8}$ The concentration of am- 
iloride used would be within that described as possessing inhibitory actions against $\mathrm{Na}^{+}$ absorption, ${ }^{9}$ although the degree of dilution that occurs at the site of action is difficult to determine. Our data suggest that changes in $\mathrm{Na}^{+}$transport and in airway hydration are not important mechanisms by which frusemide inhibits bronchoconstrictor challenges and are similar to those recently reported by Baldwin and colleagues. ${ }^{10}$ Our results are also in agreement with those of Rodwell et al who showed that inhaled amiloride did not protect against dry air challenge in asthmatic subjects in whom protection is afforded by frusemide. ${ }^{11}$ However, the negative results obtained with amiloride must be interpreted in the light of the fact that it was not possible to test higher concentrations of amiloride because of its relative insolubility.

Our studies with acetazolamide demonstrate that carbonic anhydrase inhibition provides some protective effect against MBS challenge. The dose of acetazolamide used afforded approximately half the protective effect observed with $40 \mathrm{mg}$ of inhaled frusemide. ${ }^{12}$ We used the maximum concentration of acetazolamide that could be maintained in solution and acetazolamide is a very potent inhibitor of carbonic anhydase activity in vitro. ${ }^{13}$ Frusemide has previously been shown to possess weak carbonic anhydrase inhibitory activity in the renal tubules as judged by its effect on bicarbonate excretion. ${ }^{6}$ However, because frusemide is generally more effective in inhibiting MBS-induced bronchoconstriction than acetazolamide, it is unlikely that the inhibitory effect of frusemide can be ascribed to its relatively weaker effect as an inhibitor of carbonic anhydrase. The inhibitory effect of acetazolamide is not only restricted to MBS challenges because a small but significant protective effect against bronchoconstriction induced by cold dry air challenge has recently been reported. ${ }^{14}$

The mechanism by which inhibition of carbonic anhydrase activity may be inhibiting MBS-induced bronchoconstriction in asthmatic patients is not clear. We have recently shown that acetazolamide can inhibit non-adrenergic non-cholinergic contractile responses induced by electrical stimulation in guinea pig bronchial strips by preventing the release of contractile neuropeptides from sensory nerve endings. ${ }^{15}$ Acetazolamide is known to inhibit carbonic anhydrase activity in afferent peripheral nerves of rodents. ${ }^{16}$ Although the precise mechanism of MBS-induced bronchoconstriction is not clear, it is possible that a noncholinergic non-adrenergic neural pathway may be involved ${ }^{1718}$ and acetazolamide may inhibit these pathways.

1 Kao LC, Warburton D, Cheng MH, Cedeno C, Platzker ACG, Keens TG. Effects of oral diuretics on pulmonary mechanisms in infants with chronic bronchopulmonary dysplasia: results of a double-blind cross over sequential trial. Pediatrics 1984;74:37-44.

2 Kao LC, Warburton D, Sargent CW. Furosemide acutely decreases airway resistance in chronic bronchopulmonary dysplasia. $\mathcal{F}$ Pediatr 1983;103:624-9.

3 Chung KF, O'Connor BJ. Furosemide: a new therapeutic indication for asthma? Drugs News and Perspectives 1992; 5:355-60.

4 Burg M, Stoner L, Cardinal J, Green N. Furosemide: effect on isolated perfused tubules. Am $\mathcal{f}$ Physiol 1973;225: 119-24.

5 O'Connor BJ, Chung KF, Chen-Worsdell Y, Fuller RW, Barnes PJ. Effect of inhaled frusemide and bumetanide on adenosine $5^{\prime}$ monophosphate and sodium metabisulfiteinduced bronchoconstriction in asthmatic subjects. $\mathrm{Am}$ Rev Respir Dis 1991;143:1329-33.

6 Stein JH, Wilson CB, Kirkendall WM. Differences in the acute effects of furosemide and ethacrynic acid in man. $\mathcal{F}$ Lab Clin Med 1968;71:654-5.

7 Benos DJ. Amiloride: a molecular probe of sodium transport in tissues and cells. Am $\mathcal{F}$ Physiol 1982;242:C131-45.

8 App EM, King M, Helfesrieder R, Kohler D, Matthys $H$. Acute and long-term amiloride inhalation in cystic fibrosis lung disease. Am Rev Respir Dis 1990;141:605-12.

9 Knowles M, Murray G, Shallal F, Askin F, Ranga V, Gatzy $\mathrm{M}$, et al. Bioelectric properties and ion flow across excised human bronchi. $\mathcal{F}$ Appl Physiol 1984;56:868-77.

10 Baldwin DR, Grange KL, Pavord I, Knox AJ. The effect of amiloride on the airway response to metabisulphite in asthma: a negative report. Eur Respir $\mathcal{f} 1992 ; 5: 1189-92$.

11 Rodwell LT, Anderson SD, Dutoit J Seale JP. Inhaled amiloride does not protect against dry air challenge in asthmatic subjects in whom protection is afforded by asthmatic subjects in whom protection

12 Nichol GM, Alton E, Nix A, Geddes DM, Chung KF Barnes PJ. Effect of inhaled frusemide on metabisulphite and methacholine-induced bronchoconstriction and nasal potential difference in asthmatic subjects. Am Rev Respir Dis 1990;142:576-80.

13 Maren TH. Carbonic anhydrase: chemistry, physiology and inhibition. Physiol Rev 1967;47:595-781.

14 O’Donnell WJ, Rosenberg M, Niven RW, Drazen JM, Israel E. Acetazolamide and furosemide attenuate asthma induced by hyperventilation of cold, dry air. Am Rev Respir Dis 1992;146:1518-23.

15 Sun J, Elwood W, Barnes PJ, Chung KF. Effect of thiazide diuretics against neurally-mediated contraction of guineapiuretics against neurally-mediated contraction of guineapig airways: contribution of
Respir Dis 1993;148:902-8.

16 Cammer W, Tansey FA. Immunocytochemical localization of carbonic anhydrase in myelinated fibres in peripheral nerves of rat and mouse. $\mathcal{f}$ Histochem Cytochem 1987;35 865-70.

17 Nichol GM, Nix A, Chung KF, Barnes PJ. Characterisation of bronchoconstrictor responses to sodium metabisulphite aerosol in atopic subjects with and without asthma. Thorax 1989;44:102-7.

18 Robuschi M, Gamboro G, Spagnotto S, Vaghi A, Bianco $S$. Inhaled frusemide is highly effective in preventing ultrasonically nebulised water bronchoconstriction. Pulm Pharmacol 1989;1:187-91. 